\title{
A Szerb-Horvát-Szlovén Királyság megalakulásának állomásai: 1918. október 29-től 1918. december 1-ig
}

\author{
Sokcsevits Dénes*
}

\begin{abstract}
Key events in the formation of the Kingdom of Serbs, Croats and Slovenes: October 29-December 1, 1918. The birth of the Yugoslavian state in the autumn of 1918 is associated to several symbolic events, such as the treaty of Corfu, the assembly at Újvidék, negotiations in Geneva, and prince regent Charles' Belgrade manifesto. This paper presents the complex series of events resulting in the formation of the Yugoslavian state on December 1, 1918. Events at each location are discussed, including how these fit in the developments that gave birth to the Yugoslavian state.
\end{abstract}

Keywords Great War (1914-1918), history of Central-Europe, birth of the first Yugoslav state, Corfu, Geneva, Belgrade

\section{A Nagy Háború alatti előzmények}

Az Osztrák-Magyar Monarchia délszláv (persze főleg horvát és szlovén) politikusainak többsége egészen 1918-ig, a Dunai Monarchia keretein belül képzelte el népei jövőjét, és csak a központi hatalmak világháborús veresége közeledtével kezdett számolni a Habsburgok államalakulatán kívüli megoldással, mint reális lehetőséggel, pontosabban a délszláv egységet a Monarchia felbontása árán megvalósítani kívánó politikusok egy része emigrációba ment, $\mathrm{s}$ megalakították a Jugoszláv Bizottságot, míg másik részük, a magyar kormány segítségével kormányzó Horvát-Szerb Koalíció tagjaként magyarbarátságot színlelve várta a háború végét. A két, egymástól eltérő horvát nemzetállami koncepció (a Jogpárt trialista nagyhorvát államterve, illetve a nagy délszláv egység illírizmus óta élő terve, a Szerbiával megvalósítandó nagy délszláv állam) közül az első világháború fejleményei végül a délszláv egység híveinek nyújtottak lehetőséget terveik megvalósítására. ${ }^{1}$ Igaz, már 1918-ra láthatóvá vált, hogy az egységes délszláv

\footnotetext{
* Intézmény: Magyar Tudományos Akadémia Bölcsészettudományi Kutatóközpont Email: sokcsevits@freemail.hu

${ }^{1}$ Az első világháború idején számos, a délszláv kérdés Monarchián belüli rendezésével kapcsolatos kombináció született délszláv politikusok tollából, de az összes trialista vagy dualista modellen kívüli megoldást éppen Tisza, a Munkapárt és a vezető magyar politikai körök utasították vissza a legkitartóbban, egészen az Osztrák-Magyar Monarchia összeomlásáig. Szerbia megszállása után több magyar javaslat is született a Balkán átrendezéséröl, és ezen belül a horvát és bosnyák kérdés megoldásáról is. Egyes birodalmi szemléletű megoldástervezetek (amelyek a térség feletti tartós magyar szupremáciával számoltak) teljesen átalakították volna a magyar-horvát (és persze részben az osztrák-magyar) kiegyezés rendszerét is. Akadt olyan tervezet, amely Szlavóniát, Bosznia-Hercegovinát és Dalmáciát is közvetlenül Magyarországhoz csatolta volna, és teljes mértékben figyelmen kívül hagyta volna nemcsak a horvát politikai érdekeket, de a horvát nemzeti integráció előző néhány évtizedben lezajlott, Az ilyen nagy horderejü és a kettős Monarchia közjogi berendezkedését, kényes politikai egyensúlyi viszonyait felborogatni kívánó elképzeléseket, amelyek Magyarország tényleges súlyának és erejének túlbecsülésére alapozódtak, persze Tisza István miniszterelnök és kormánya nem osztotta. Igaz, más, a horvátok szempontjából előnyös tervezeteknek sem nyújtott támogatást.
} 
államról eltérő elképzelései vannak a szerbiai, valamint a Monarchiabeli szerb, illetve a szlovén és horvát politikusoknak.

Már 1914-ben megfogalmazódott, hogy a horvátok világháborús áldozatvállalásuk alapján igénylik Horvátország közjogi helyzetének megváltoztatását. Erről Ivan Skerlecz bán 1914 végén így nyilatkozott: „,Feljogositva látják magukat arra, hogy a háború utáni idöre nagy nemzeti vívmányokat kívánjanak. "2

A Frank-féle Jogpárt képviselői osztrák katonai körökre támaszkodva egyre erőteljesebben lobbiztak a Monarchia trialista átalakításáért, amit a magyar kormányzat határozottan ellenzett, Tisza István pedig e törekvésekről igen negatívan vélekedett: „, $A$ horvátok tetemes része trialista nagyhorvát hóbortok tévútjain kalandozik. "’

Noha a horvát saborban már 1915-ben is nyíltan vitáztak a horvát államjogi helyzet lehetséges megváltoztatásáról, ezek az elképzelések legalább részleges esélyt csak a dualista rendszerhez mindvégig ragaszkodó Ferenc József halála után, IV. Károly trónra lépése után kaptak. Utóbbi ugyanis országa megmentése érdekében hajlott a kettős államjogi berendezkedésen túlmutató megoldásokra. Nem véletlen, hogy 1917-töl sokasodtak meg az ilyen irányú politikai tapogatózások, kulisszák mögötti vagy éppenséggel nyílt, parlamenti fellépések, valamint a megoldásokat kínáló tervezetek, pro memóriák, könyvek, kiáltványok. A Monarchia trialista átalakítását követelő megnyilvánulások közül az egyik legtöbbet emlegetett esemény a IV. Károly által összehívott ciszlajtán parlament délszláv (dalmáciai és isztriai horvát, valamint szlovén) képviselői által 1917 májusában elfogadott Májusi Deklaráció, amelynek megalkotói azonban, amint azt maguk is elismerték, valójában nem átalakítani, hanem felbontani akarták a Habsburg Monarchiát.

Velük ellentétben a Tiszta Jogpárt, valamint olyan kiemelkedö boszniai közszereplök, mint a szarajevói érsek, Josip Stadler vagy a neves értelmiségi, Ivo Pilar, akik elutasították a jugoszláv koncepciót, és komolyan úgy gondolták, hogy a horvátság érdekeit a Monarchia fennmaradása szolgálja, különböző, a dualista és trialista rendszert látszólag, formálisan összeegyeztethető megoldásokat javasoltak. Noha elöször ők is üdvözölték a Májusi Deklarációt, nagyon hamar belátták, hogy annak valódi célja a Monarchia felbomlasztása. Ezért még 1917 nyarán Stadler és köre összeállított IV. Károly számára egy emlékeztetőt, amelyben a Monarchia általános rekonstrukciójával összhangban egy Horvátországból, Szlavóniából, Dalmáciából, Bosznia-Hercegovinából kialakított közigazgatási egységet teremtene, amely Boszniához hasonlóan mintegy kondomíniumként (közös igazgatású területként) kapcsolódna Ausztriához és Magyarországhoz. ${ }^{4}$

A legtöbb tervezetet, könyvet, vitairatot mind horvát, mind német nyelven Ivo Pilar írta (alighanem a Pro memoria koncepciójának kialakításában is részt vállalt). Pilar is 1918-ig figyelembe véve az osztrák-magyar viszony kényes egyensúlyát, megkísérelte valahogy összeilleszteni valójában trialista elképzeléseit a dualista rendszerrel. A végén azonban már nyíltan a trialista megoldást tartotta a Monarchia megmentése utolsó esélyének. ${ }^{5}$

Nem jelentett előrelépést Tisza István IV. Károly megbízásából tett 1918. szeptemberi délszláv körútja sem. Szarajevóban Tisza szembesült a szeparatista délszláv

\footnotetext{
${ }^{2}$ In: Magyarország története 7. rész, II. k. 1113. A következő Tisza idézet ugyanott.

${ }^{3}$ Uo.

${ }^{4}$ Promemoria über die Lösung der südslavischen Frage. Stadler politikai tevékenységéről lásd újabban: Grijak, Zoran: Politička djelatnost vrhbosanskoga nadbiskupa Stadlera, 2001, Zagreb.

${ }^{5}$ Legismertebb művei: Svjetski rat i Hrvati, 1915 és 1917, Zagreb; Die südslavische Frage und der Weltkrieg. Übersichtliche Darstellung des Gesamt-Problems, 1918, Wien. Horvátul: Južnoslavensko pitanje. Prikaz cjelokupnog stanja, 1943, Zagreb. Pilar első világháború alatti politikai tevékenységéről és a horvát kérdés rendezésével kapcsolatos terveiröl lásd: Matijević, Zlatko: Hrvatsko-mađarski državnopravni odnosi u svjetlu političkih koncepcija Dr. Ive Pilara, in: Milan Kruhek főszerk.: Hrvatsko-mađarski odnosi 1102-1918, 2004, Zagreb, Zbornik radova, Hrvatski institut za povijest, 287-302.
} 
törekvésekkel és az ellenséges közhangulattal. A délszláv különállás jegyében fogant memorandumot átadó szerb és horvát képviselőkkel szembeni haragos fellépése, fenyegetése (,,Magyarország elég erős, hogy mielött elpusztulna, ellenségeit összezúzza”) nem ért célt, a delegáció tagjai egyszerüen hátat fordítottak neki, és otthagyták. $^{6}$

Másnap Tisza fogadta a Monarchia fenntartásában érdekelt horvát jogpárti érzelmü Ivo Pilart is, de továbbra is mereven ragaszkodott a dualista rendszer fenntartásához. Ekkor alighanem a trialista megoldásra már amúgy sem maradt volna idő és lehetőség. Talán 1917-ben, vagy legkésőbb 1918 tavasza előtt, amikor még az antant hatalmak nem döntöttek a Habsburg Monarchia szétveréséröl, lett volna esélye egy ilyen típusú államjogi rendezésre, de sajnos Tisza és még sokan mások Budapesten még a lengyelekkel kapcsolatban is elutasították a dualista rendszerrel ellentétes terveket, még kevésbé voltak hajlandók ilyen ötletek támogatására a délszláv térségben. ${ }^{7}$

$\mathrm{Az}$ Osztrák-Magyar Monarchia felbomlásához vezető események 1918 októberében felgyorsultak. Bár Ljubljanában a Monarchia osztrák fele délszláv lakóinak képviseletére vállalkozó Nemzeti Tanács (Narodni svet) már 1918 júliusában megalakult, az egész szlovének, horvátok, szerbek által lakott terület (tehát a Magyar Koronához tartozó Horvát-Szlavónország és az osztrák-magyar kettős uralom alatti BoszniaHercegovina) kormányzását kezébe venni akaró zágrábi Szlovén-Horvát-Szerb Nemzeti Tanács csak 1918. október 6-án jött létre.

A Horvát-Szerb Koalíció pedig unionista (magyarbarát) álarcát csak október 12-én vette le, és Pribičević vezetésével csatlakozott az egységes délszláv állam megalakítását célul kitüző zágrábi Nemzeti Tanácshoz. A Tanács elnöke a szlovén Anton Korošec lett.

IV. Károly 1918. október 16-i nyilatkozata a Monarchia föderációvá alakításáról már nem befolyásolta a délszláv térség eseményeit, különös tekintettel a francia és szerb csapatok balkáni sikereire (Bulgária katonailag összeomlott, és az antant erői elől az osztrák-magyar és német csapatok megkezdték a visszavonulást. Tisza István is ekkortájt, október 17-én ismerte el a magyar parlamentben a háborús vereséget). Tisza István (és Wekerle Sándor is) csak ekkor változtatott horvát politikáján. Tisza október 22-én fogadta a Tiszta Jogpárt képviselöit, Ivo Frankot és Aleksandar Horvatot. Elismerte, hogy korábbi politikája hibás volt, és a horvátoknak joga van a függetlenséghez. Ez azonban már csak jelképes gesztusnak tekinthető (különben is állítólag három nappal később mégis az államközösség fenntarthatósága mellett érvelt). Ekkor már Horvátország és Bosznia-Hercegovina végérvényesen elveszett Magyarország számára. ${ }^{8}$

\section{Zágráb: 1919. október 30.}

\footnotetext{
${ }^{6}$ Tisza útjáról lásd: Krizman 1989, 251-261. old. Magyarul: Tonelli Sándor: Tisza István utolsó útja (Sarkotić István báró vezérezredes, Bosznia-Hercegovina utolsó tartományfönökének naplója) 1941, Szeged, illetve Nádasdy Béla: Az utolsó kísérlet 1918, 1938, Budapest. Sarkotić maga is a trialista gondolattal szimpatizált, és emiatt hozta össze másnap Tiszát Pilarral, persze eredmény nélkül. Egyébként maga az egykori magyar miniszterelnök is elismerte, hogy a háború utolsó két évében nem tájékozódott kellő alapossággal a délszláv helyzetről. Hozzátenném, előtte pedig az általa támogatott Pribičevićtől, vagy utóbbi Koalíción belüli helyettesétől, Dušan Popovićtól (aki Tisza teljes bizalmát élvezte a háború során) aligha kaphatott őszinte, hiteles tájékoztatást.

${ }^{7}$ Tisza szentül meg volt győződve, hogy Magyarország kizárólag egy dualista Monarchiában maradhat fenn, és bármely megoldás, amely a magyarság vezető szerepét gyengítené, elfogadhatatlan volt számára. Ezért nem támogatta még a lengyel trialista törekvéseket sem (az oroszok által megszállt lengyel területek és Galícia egyesítését a Monarchián belül). Ez utóbbi miatt ifj. Andrássy Gyula is bírálta, aki számára egy ilyen megoldás elfogadható lett volna. Lásd Vermes Gábor: Tisza István, 1994, Budapest, Századvég Kiadó, 346.

${ }^{8}$ Ezt a közös külügy egyik magyar tisztviselöje, gróf Ambrózy Lajos meg is mondta Tiszának. (Vermes 1994, 479-480. old.)
} 
Zágrábban már október 22-én spontán demonstrációkra került sor, amelyeken a horvátok számára önrendelkezést követelte a tömeg. A tömegmegmozdulásra azt követően került sor, hogy nyilvánosságra került: Wilson amerikai elnök elutasította az Osztrák-Magyar Monarchia békeajánlatát és válaszában megemlítette a Monarchia délszláv népeinek önrendelkezéshez való jogát. ${ }^{9}$ A zágrábi Nemzeti Tanács támogatásáról biztosította a tüntetőket, de még aggódott, hogy a Zágrábban nagy számban állomásozó osztrák-magyar katonaság vajon hogyan cselekedne, ha kikiáltanák az elszakadást a kettős monarchiától. A Nemzeti Tanács kapcsolatba lépett a közös hadsereg horvát tábornokaival, akik elutaztak Bécsbe, hogy megtudják, hogy az adott szituációban mit tegyenek. Az uralkodó, IV. Károly feloldotta őket esküjük alól, s október 28án reggel a Nemzeti Tanács képviselöi már tudták, hogy az elszakadást nyugodtan kikiálthatják, a hadsereg nem fogja megakadályozni. Ugyanaznap bejelentették Csehszlovákia megalakulását. ${ }^{10}$ Időközben spontán hatalomátvételre került sor Fiumében: a közös hadsereg egy horvát alakulata felszámolta a magyar közigazgatást. ${ }^{11}$

Zágrábban időközben a Nemzeti Tanácson belül viták folytak arról, hogy összehívják-e a horvát sabort (különösen Pribičević ellenezte), de végül mégis a horvát törvényhozással mondatták ki Zágráb Budapesthez és Bécshez füződő sok évszázados kapcsolatainak megszüntetését. Erről a horvát történelemben fontos szerepet játszó októberi napról rendelkezünk visszaemlékezésekkel, éppen azért, mert az események a zágrábi lakosság, a polgárság, illetve az „utca embere” bevonásával zajlottak, részben spontán, részben szervezett módon. $^{12}$

A Nemzeti Tanács október 28-án késő estig tanácskozott, hogy elökészítse a másnap a sabornak benyújtandó határozati javaslatokat a horvát-magyar kiegyezés felmondásáról, a Monarchiától való elszakadásról, illetve arról, hogy a horvát törvényhozás adja át a hatalmat a Nemzeti Tanácsnak, amely eldöntötte, hogy a dunai monarchia délszlávok lakta területein megalakítja a Szlovén-Horvát-Szerb Nemzeti Tanács Államát. A horvát bán, Antun Mihalovich a Horvát-Szerb Koalíció embere volt, így nem gördített semmiféle akadályt a tervezet elé, támogatta a Nemzeti Tanács törekvéseit.

Október 29-én reggel 8 órakor kezdett gyülekezni az egyetemi és középiskolai ifjúság, valamint horvát honvédek és a közös alakulatok horvát és cseh katonái, valamint felszabadított szerb hadifoglyok az Egyetem előtti téren a Horvát Nemzeti Színház mellett. Egyre több városi polgár is csatlakozott a tömeghez, lengtek a horvát, szerb és szlovén nemzeti zászlók, zengtek az illír korszk harcias dalai, a davoriják és más hazafias énekek. Körülbelül 9 óra tájban a tömeg elindult a Frankopansa utcán és az Ilicán át fel az Óvárosba és összegyült a horvát törvényhozás 1913-ban épült új épülete elött a felsővárosi Szent Márk téren. Josip Horvat visszaemlékezései szerint a hangulat ünnepélyes volt, bár a sabor körülbelül két és fél óráig tartó ülésezése alatt érezhető volt némi feszült várakozás, bár mindenki arra számított, hogy a törvényhozás a függetlenség kikiáltása mellett fog dönteni.

A sabor 10 óra 30 perckor kezdett ülésezni. Az ülést a törvényhozás elnöke, a szerb származású Bogdan Medaković nyitotta meg, s lelkesítő szózata után átadta a szót a HorvátSzerb Koalíció szerb társelnökének, a Svetozar Pribičevićnek, aki részletesen ismertette a sabornak benyújtandó határozati javaslatokat, amelyeket a Nemzeti Tanács és a Koalíció képviselöi előző este fogalmaztak meg. A sabor mindegyik javaslatot egyhangúlag, közfelkiáltással fogadta el. A sabor felmondta a horvát-magyar kiegyezést, megszakította az

\footnotetext{
${ }^{9}$ Gulyás László-Szávai Ferenc 2018, 46-51.

${ }^{10}$ Bővebben lásd Gulyás László 2008/a, 125-134.; Gulyás László 2008/b, 138-143.

${ }^{11}$ Gulyás László-Bali Lóránt 2011, 143-150.; Gulyás László-Bali Lóránt 2012/b, 41-53.

12 Elsősorban Josip Horvat memoárjaira támaszkodtam: Horvat, Josip 1984, 137-139. illetve ugyanő még részletesebben ismerteti az eseményeket alábbi könyvében: Horvat, Josip 1936, 81-102.
} 
államjogi kapcsolatokat Magyarországgal és Ausztriával, s határozatban átadta a hatalmat a Nemzeti tanácsnak, hogy kormányozza a Monarchia délszlávok lakta területeit az egységes délszláv állam megalakulásáról és államjogi berendezkedéséröl a közeljövőben összehívni tervezett közös délszláv alkotmányozó nemzetgyülés döntéséig. A sabor ülésén a határozat elfogadása mellett érvelt Mihalovich bán is, $\mathrm{s}$ a Koalíció horvát társelnöke Ante Pavelić is (aki csak névrokona volt a későbbi usztasa vezérnek), sőt a parasztpárti Stzjepan Radić is. A trialista irányzatot képviselő Jogpárt képviselöje, Vladimir Prebeg is alávetette magát a Nemzeti Tanács jövendő kormányának, $\mathrm{s}$ bejelentette, hogy a párt a választmány következő ülésén feloszlatja magát (ezt teljesen önkényesen cselekedte, párttársai megkérdezése nélkül). Miután a képviselők határozatokat és az ülés jegyzőkönyvét is elfogadták, 12 óra 50 perckor az ülést berekesztették, majd a sabor erkélyéről Grga Angjelinović, Svetozar Pribičević és Antun Mihalovich bán szóltak az egybegyültekhez. A magyarsággal szembeni ellenérzések eluralkodásáról árulkodik, hogy amikor a nyolc évszázados horvát-magyar államközösséget a horvát sabor 1918. október 29-én felmondta, azzal nemcsak a képviselők, de a horvát társadalom túlnyomó része is egyetértett, és a jelenlevő többezres tömeg felszabadulásként élte meg a válás egyoldalú kimondását. A tömeg elénekelte a horvát, majd a szerb himnuszt, végül a Marseilles-t is. A katonákat megkérték, hogy délután 3 órára vonuljanak vissza a kaszárnyáikba. A tömeg ezután elvonult, de késő estig valóságos népünnepély zajlott a városban.

Azonban nem mindenki ünnepelt. A magyarbarát közszereplök és a Tiszta Jogpárt hívei ezekben a napokban félelemben éltek. Iso Kršnjavi, aki Khuen Héderváry Károly bán egykori kultuszminisztere (a vallás és közoktatási osztály vezetője) volt, ezekben a napokban azt hallotta, hogy fel akarják akasztani, s még végrendeletet is készített. Öt nemcsak egykori kormányzati szerepvállalásáért gyülölték a jugoszláv egység hívei, hanem azért is, mert miután nyugdíjba vonult, a Tiszta Jogpárt híveként a Monarchia fenntartását célzó trialista törekvéseket támogatta. ${ }^{13}$ Végül nem bántották, Zágrábban nem voltak atrocitások, de vidéken a zöld káder (katonaszökevényekből és bűnözőkből szerveződött bandák) gyilkolt és fosztogatott, etnikai jellegü, s antiszemita támadásokat is elkövetett.

Az első világháború végén a horvát politikai elit tagjai között, de leginkább a fiatalabb generációk soraiban még sokan őszintén hittek a délszláv egység üdvös voltában, és 1918. október 29-én a horvát sabor lelkesen mondta ki a Monarchiától való elszakadást, és egyben megalakította a Szlovén-Horvát-Szerb Nemzeti Tanács Államát. Elvben a Habsburg Monarchiához tartozó valamennyi délszláv terület hozzátartozott, így a mai Szlovénia, Horvátország, Bosznia-Hercegovina és a Vajdaság. A képviselők aligha gondolták, hogy az elkövetkezö húsz évben nem lesz több horvát országgyülés. A Magyarországgal való kapcsolat megszakításakor biztosan nem jártak eszükben Deák Ferenc 1868-ban Jovan Živkovićhoz intézett szinte prófétai szavai: „Tudom, hogy Horvátországban valamiféle délszláv birodalomról álmodoznak. (...) Ha ez valaha is megvalósul - jegyezze meg -, annak a központja nem Zágráb, hanem Belgrád lesz."

Más kérdés, vajon az adott történelmi pillanatban volt-e más választása Horvátországnak. Nagyon is valószínü, hogy amennyiben a horvátok az egyesülés ellen szavaztak volna, az antanthatalmak a horvát etnikai terület rovására jutalmazták volna meg háborús szövetségeseiket, Szerbiát és Olaszországot.

\section{Zágráb és Belgrád között}

Az antant vezető hatalmai - miután elálltak a Habsburg Monarchia fenntartásának szükségességétől - (tévesen) úgy vélték, minél nagyobb méretü utódállamokat kell

\footnotetext{
${ }^{13}$ Iso Kršnjavi 1986, 807-808.
} 
létrehozni, mert azok így képesek lesznek ellenállni egy idővel újra talpra álló Németország nyomásának. Emiatt nem támogatták a szerb elképzeléseket egy megnagyobbított Szerbiáról, hanem nyomást gyakoroltak a szerb kormányra, hogy fogadja el az Alpoktól a Vardarig terjedő Nagy-Jugoszlávia gondolatát, és ne csak minden szerbet, hanem minden szlovént és horvátot is egyesítsen. A szaloniki front áttörése után, 1918 októberében, miközben a szerb hadsereg és antant szövetségesei már mélyen Szerbiában jártak, Pašić újra Nagy-Szerbia létrehozása érdekében tárgyalt Párizsban, Rómában és Londonban is, úgy állítva be a korfui nyilatkozatot, mintha az szerb részről csak propagandafogás lenne, nem pedig a kormányfö aláírásával hitelesített, kötelező érvényü dokumentum. Jugoszlávia létrehozásának szükségességéről 1918. október 8 -án Londonban elöbb Wickham Steed győzködte, de kevés sikerrel, pedig a nyilvánosság nyomását is felhasználta: a New Europe éppen ekkor ilyen szellemü cikket közölt. Minderről Steed még aznap beszámolt Balfournak. ${ }^{14}$ Végül Balfour brit külügyminiszter meggyőzte Pašićot, nincs más választása, mint elfogadni az egységes délszláv államot, mert a szövetségesek így akarják (mielőtt a szerb miniszterelnökkel találkozott volna, a brit politikus aznap délelőtt fogadta Trumbićot, és biztosította öt, London támogatja a jugoszláv állam megalakítását). ${ }^{15}$

A Jugoszláv Bizottság, illetve az időközben megalakult zágrábi Szlovén-HorvátSzerb Nemzeti Tanács és a szerb kormány között azonban november elején is elkeseredett vita folyt arról, hogy az új állam egyenrangú népek föderációja vagy Belgrád-központú, erősen centralizált ország legyen. A vitázó feleket végül az antant ültette tárgyalóasztalhoz Genfben, 1918. november 5. és 9. között, és a genfi nyilatkozatban a szerb kormányfő kénytelen-kelletlen ráállt egy szövetségi állami modell elfogadására. Mindezt nem meggyőződésből, csak brit-francia-amerikai nyomásra cselekedte (Wilson már a Habsburg Monarchia átalakítása kapcsán is a föderációt támogatta, $\mathrm{s}$ az új délszláv államalakulatot is így képzelte el). November 7-én ugyanis a szerb miniszterelnök táviratot kapott Poincaré francia köztársasági elnöktől, és ebben a francia politikus ilyen nagy szavakkal próbálta rávenni Pašićot a föderáció (s egyben Nagy-Jugoszlávia) elfogadására: „Öszintén szeretném, ha az egész jugoszláv törzs, mint egységes lélek jelentkezne, s a legkisebb megosztottság nélkül, mert ezt most jobban, mint bármikor eddig, megkövetelik létérdekeink." ${ }^{16}$

Pašić kénytelen volt figyelembe venni szövetségese, Franciaország létérdekeit. Protić és a többi radikális párti politikus felháborodással fogadta a genfi nyilatkozatot, és Pašić hazatérve a nemrég felszabadított Belgrádba, rövidesen vissza is vonta a szövetségi államra vonatkozó ígéretét. Meg kell azonban jegyezni, hogy a Csehszlovák Bizottsággal ellentétben az antant nem ismerte el hivatalos tárgyalópartnernek sem a Jugoszláv Bizottságot, sem a Zágrábban 1918. október 29-én kikiáltott Szlovén-Horvát-Szerb Államot, és ezzel elönyös helyzetbe hozta a szerb kormányt.

Pašić könnyedén visszavonhatta genfi ígéretét, mert 1918 őszén a győzedelmesen elörenyomuló szerb hadsereg vált a délszláv egyesítés fö tényezőjévé, valamint, bár Rómának korántsem ez volt a célja, az Adria keleti partját egyre gyorsabb ütemben megszálló olasz haderő (emiatt a horvát és szlovén politikusok kezdték maguk is sürgetni az egyesülést Szerbiával). A maga részéről a zágrábi Szlovén-Horvát-Szerb Nemzeti Tanács elnökhelyettese, Svetozar Pribičević ugyancsak mindent elkövetett, hogy

\footnotetext{
${ }^{14}$ Seton-Watson, Steed és a New Europe köre komoly befolyást gyakorolt a brit politikára, és ez a befolyás Magyarország sorsára is erösen kihatott.

${ }^{15}$ Mandić 1956, 74-75. old. Pašićot maga Balfour figyelmeztette, hogy a szövetségesek a korfui nyilatkozatot, rajta a szerb miniszterelnök aláíásával nem tekintik pusztán propagandaanyagnak, hanem komoly szándéknyilatkozatnak veszik.

${ }^{16}$ Mandić 1956, 86.
} 
felgyorsítsa az egyesülési folyamatot Szerbiával, és megüzente a szerb miniszterelnöknek, ne törödjön a genfi nyilatkozattal. Ugyanakkor Karadjordjević Sándor régens is egy Belgrád központú, centralizált állam híve volt, és ezek a tényezők eleve behatárolták a horvát politikusok mozgásterét.

A belgrádi politikusok a genfi egyezményt félredobták, és csak az abban foglalt föderatív elvek mellözésével tartották végrehajthatónak az egyesülést. Közben gyorsan azon dolgoztak, hogy Boszniában, a Bácskában ${ }^{17}$, a Bánságban, a Szerémségben a zágrábi Nemzeti Tanács megkerülésével megszervezzék az említett területek egyesülését Szerbiával. A zágrábi Nemzeti Tanács nem volt ura a helyzetnek: vidéken katonaszökevényekből alakult rablóbandák, az ún. zöldkáder garázdálkodott (egész településeket is feldúltak, közöttük egy kisvárost is, Nova Gradiškát), a korábbi államigazgatás széthullóban volt, a parasztok földosztást követeltek (utóbbira a Nemzeti Tanács november folyamán ígéretet tett). Dalmáciában az olasz hadsereg egyre-másra foglalta el a szigeteket és városokat, nemcsak a tengerparton, de már a szárazföld belsejében is (bevonultak Kninbe is, sőt, számos olyan helységbe, amely még az 1915-ös londoni egyezmény alapján sem járt volna nekik). A Nemzeti Tanács képtelen volt új hadsereget szervezni, tétovázott, eleinte ugyan nem akarta, hogy a szerb hadsereg nagyobb erőkkel jelenjen meg az országban, de nem tanúsított nagy ügybuzgalmat a saját haderő létrehozásában sem, pedig IV. Károly utasítására a császári és királyi hajóhad utolsó fóparancsnoka, Horthy Miklós az Osztrák-Magyar Monarchia teljes flottáját átadta a zágrábi kormány képviselőinek, tehát lett volna mivel ellenállni az olasz hódításnak. ${ }^{18}$

A Szlovén-Horvát-Szerb Nemzeti Tanács 1918. november 24-i ülésén némi fenntartásokkal ugyan, de végül Svetozar Pribičević horvátországi szerb politikus sürgetésére elfogadta az egyesülés belgrádi feltételeit. Igaz, kidolgozott egy óvatos hangú követutasítást, amely egy decentralizált államberendezkedést támogatott volna, és amelyhez elvben a Belgrádba utazó delegáció tagjainak tartania kellett volna magukat. Stjepan Radić parasztpárti képviselő azonban drámai hangú beszédében figyelmeztette a résztvevőket, hogy micsoda veszéllyel járhat Horvátország államiságának feladása. Érthetetlennek tartotta, hogy azt az autonómiát, amiért annyit huzakodtak Budapesttel, most önként, harc nélkül feladják. Radićra azonban akkor a Nemzeti Tanácsban senki sem Ugyan Pavelić Pribičevićhallgatott, sőt, meg is nehezteltek rá, mert kimondta, hogy a testület nem legitim, nem képviselheti a horvát nép akaratát, mivel nem választások útján jött lére Pribičević olyannyira fenyegető magatartást tanúsított vele szemben, hogy a horvát politikus néhány hétre Prágába távozott, és az egyesülés napjaiban nem is volt otthon (a szerb politikus november folyamán szerb fiatalokból és a délszláv egység fanatikus horvát híveiből politikai nyomásgyakorlás céljából agresszív csoportokat szervezett, akik a november 24-i ülés idején az utcán Radić felakasztását követelték).

\section{Belgrád: 1918. december 1.}

\footnotetext{
${ }^{17}$ Gulyás László 2012/a, 92-95.

${ }^{18} \mathrm{Az}$ olaszok ezt a gesztust igen rossz néven vették, hiszen egy erős hajóhaddal rendelkező délszláv állam veszélyeztette volna adriai pozícióikat, ezért mindjárt egy diverzáns akcióval fel is robbantották a flotta vezérhajóját, a Viribus Unitist, s odaveszett az új horvát főparancsnok, Janko Vuković Podkapelski sorhajókapitány is. Horthy emlékirataiból egyébként szintén látszik, a zágrábi Nemzeti Tanács képviselői nem álltak a helyzet magaslatán, mert úgy jöttek Pulába átvenni a flottát, hogy nem is jutott eszükbe, döntést kellene hozni az új főparancsnok személyéröl. Végül azon hirtelenjében a régi fóparancsnok személyi javaslatát kénytelen-kelletlen elfogadták: Vukovićot, Horthy zászlóshajója parancsnokhelyettesét ideiglenesen a hajóhad élére helyezték. Horthy úgy tudta, hogy IV. Károlyt horvát származású tábornokok vették rá arra, hogy a zágrábi Nemzeti Tanács kapja meg a flotta feletti rendelkezést. Horthy Miklós: Emlékirataim, 1993, Budapest, Európa-História Kiadó, 110-112. Az antant később megosztotta a flottát az olaszok és a jugoszlávok között.
} 
A Nemzeti Tanács delegációja végül elutazott a szerb fóvárosba, de nem ragaszkodott a még oly óvatosan megfogalmazott követutasításokhoz sem. A Nemzeti Tanács elnöke, Korošec és a Jugoszláv Bizottság vezetője, Trumbić is külföldön voltak, nem utaztak a szerb fövárosba.

Ante Pavelić és Svetozar Pribičević november 30-án este hosszasan vitatkoztak a felirat szövegén, de végül a szerb politikus álláspontja győzött, igaz, ehhez kellett a dalmát politikus Josip Smodlaka békéltető beavatkozása, aki az olasz veszélyre hivatkozva a Koalíció horvát vezetőjét álláspontja feladására vette rá. 1918. december elsején (ugyanaznap, amikor a gyulafehérvári román gyülés kimondta Nagy-Románia megalakulását) belgrádi rezidenciáján napközben csak Pribičevićet fogadta Sándor régensherceg. A delegáció többi tagja számára aznap este rendezett egy fogadást. A fogadáson a zágrábi küldöttség felolvasta feliratát, amelyben hitet tett az új állam mellett, és elismerték a királyságot és a szerb dinasztia uralmát, de Karađorđević Sándor a szerb parlamenti képviselők jelenlétében nem a zágrábi Nemzeti Tanács feliratára válaszolt, hanem ünnepélyesen bejelentette a Szerb-Horvát-Szlovén Királyság megalakulását. Az új állam megalakulását a jelenlevők megéljenezték, de a belgrádi utcán semmiféle ünneplés nem volt.

Az egyesülés tehát megtörtént. A Zágrábban állomásozó horvát honvédezredek katonái 1918. december 5-én tüntettek az egyesülés, illetve a horvát államiság megszüntetése ellen. A tüntetés spontán módon alakult ki, nem a Jogpárt szervezte. A horvát köztársaságot, a függetlenséget éltető, de időnként szocialista jelszavakat is kiáltozó tömeg tüntetését azonban a Nemzeti Tanács karhatalmi erői vérbe fojtották, a sortüzben 13 személy vesztette életét, és 17 megsebesült. ${ }^{19} \mathrm{Az}$ új belügyminiszter, Svetozar Pribičević rövidesen gondoskodott arról, hogy az 1868-as magyar-horvát kiegyezés alapján létrehozott horvát honvédséget feloszlassák (a Nemzeti Tanács honvédelmi osztályát megszüntették), és a bevonuló szerb katonaság ügyeljen a rendre. A horvát honvédezredek tisztjeit jórészt elbocsátották, a legénységet pedig 1918 decembere után szerbiai helyőrségekbe vezényelték át.

December 20-án létrejött az új ideiglenes kormány is, Stojan Protić radikális párti szerb politikus vezetésével, a miniszterelnök-helyettes a zágrábi Nemzeti Tanács elnöke, a szlovén Anton Korošec lett. A kormánytagok nemzetiségi összetétele nagyjából megfelelt az államalkotó nemzetek közötti aránynak (11, a kormányfővel együtt 12 szerb, 5 horvát, 2 montenegrói, 2 szlovén, 1 muzulmán). Ante Trumbić, a Jugoszláv Bizottság elnöke a külügyminiszteri posztot kapta, ami a horvátok számára rendkívül fontosnak bizonyult: a dalmát politikus ugyanis minden antantkörökben szerzett ismeretségét és befolyását felhasználta, hogy megvédje szülőföldjét az olasz terjeszkedéstől.

Az új állam különböző békeszerződésekkel (trianoni, saint-germain-i, neully-i, illetve az Olaszországgal kötött rapallói szerződés) elismert területe 248978 négyzetkilométer lett. Az ország 11 millió 984 ezer lakosából (montenegróiakkal együtt) 43\% volt szerb, 23\% horvát, 8,5\% szlovén, 5\% macedón (de öket is automatikusan a szerbek közé számították), $6 \%$ bosnyák (muzulmán). Ezek az adatok azonban utólagos számítások alapján születtek, mert az első délszláv állam statisztikáiban az államalkotó délszláv népek közül csak a szlovének szerepeltek külön, a horvátok, szerbek, montenegróiak, muzulmánok stb. mind együtt voltak feltüntetve, és így elvben a „szerbhorvátok” az ország lakosságának 74 százalékos többségét

\footnotetext{
${ }^{19}$ Matković, Hrvoje: Povijest Jugoslavije (1918-1991), 1998, Zagreb, Hrvatski pogled. PIP, 84. old. Más adatok szerint 15 halott és 20 sebesült áldozat volt. Goldstein, Ivo: Hrvatska 1918-2008., 2008, Zagreb, EPH Liber, 30 .
} 
alkották. Volt még kb. 4,2\% német, 3,9\% magyar, 3,7\% albán (összesen a lakosság kb. 14,5 százaléka volt valamely nem délszláv kisebbség tagja). ${ }^{20}$

Az új állam így valójában nem volt nemzetállam, bár az egységes délszláv nemzet kialakításának hívei azt hitték, sikerrel járnak. Nem így lett, s a kudarcért alig több mint húsz esztendővel később az állam valamennyi nemzete és nemzeti kisebbsége súlyos árat fizetett.

\section{Felhasznált irodalom}

Grijak, Zoran 2001, Politička djelatnost vrhbosanskoga nadbiskupa Stadlera, 2001, Zagreb. Gulyás László 2008/a, Edvard Beneš. Közép-Európa koncepciók és a valóság. Máriabesnyő-Gödöllő: Attraktor Kiadó. 125-134. old.

Gulyás László 2008/b, Beneš statesman or charlatan? The plans and the reality 19081948. Toronto-Buffalo: Corvinus Publishing.

Gulyás László 2012/a, A Délvidék története 2. A török kiüzésétől Trianonig 1683-1920.

Közép-Európai Monográfiák 6. Egyesület Közép-Európa Kutatására. Szeged.

Gulyás László-Bali Lóránt 2011, The Fiume question 1918-1920. Öt Kontinens. 2011/1. 143-150. old.

Gulyás László-Bali Lóránt 2012/b, Ten years from the history of Fiume, 1914-1924. The Twentieth Century. 2012/2. 41-53. old.

Gulyás László-Szávai Ferenc 2018, Közép-Európa és Wilson 14 pontja. BBC History 2018/október 46-51. old.

Horthy Miklós 1993, Emlékirataim. Budapest: Európa-História Kiadó.

Horvat, Josip 1936, Politićka povijest Hrvatske. Zagreb.

Horvat, Josip 1984, Živjeti u Hrvatskoj. Zapisci iz nepovrata 1900-1941. SNL. Zagreb. Iso Kršnjavi 1986, Zapisci iza kulisa hrvatske politike, Mladost. Zagreb. I-II. kötet.

Matijević, Zlatko 2004, Hrvatsko-mađarski državnopravni odnosi u svjetlu političkih koncepcija Dr. Ive Pilara, in: Milan Kruhek főszerk.: Hrvatsko-mađarski odnosi

1102-1918. Zagreb, Zbornik radova, Hrvatski institut za povijest, 287-302. old.

Matković, Hrvoje 1998, Povijest Jugoslavije 1918-1991. Zagreb.

Nádasdy Béla 1938, Az utolsó kísérlet 1918. Budapest.

Rotschild, Joseph 1996, Jugoszlávia története a két világháború között. JATEPressz. Szeged.

Tonelli Sándor 1941, Tisza István utolsó útja. Sarkotić István báró vezérezredes, Bosznia-

Hercegovina utolsó tartományfőnökének naplója. Szeged.

Vermes Gábor 1994, Tisza István. Századvég Kiadó. Budapest.

A müre a Creative Commons 4.0 standard licenc alábbi típusa vonatkozik: CC-BY-NC-ND-4.0.

\section{$( c ) \longdiv { B Y - N C - N D }$}

\footnotetext{
${ }^{20}$ Rotschild, Joseph 1996, 7. old., illetve I. táblázat.
} 